\title{
UNUSUAL METEOROLOGICAL PHENOMENA AT TÂRGU MUREŞ IN THE LAST YEARS
}

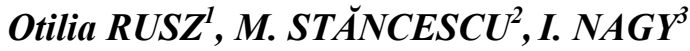

\begin{abstract}
Unusual meteorological phenomena at Târgu Mureș in last years. Meteorological observations at Târgu Mureș are effectuated from the second half of $19^{\text {th }}$ century. The weather station functions at the actual location since 29 May 2013. In the current place environment conditions have not changed significantly, but the new site of the station is closer to Azomureș Chemical Factory, which is the biggest polluter of Mureș County. Haze and smoke are very rare phenomena hence at Târgu Mureș haze and (industrial) smoke were reported 18 times within two years (2014-2015). The snowfall of $31^{\text {th }}$ of December 2014 in Târgu Mureș was uncommon due to the existing weather conditions. An anticyclone was located over the region, and no precipitations were forecasted. At the same time in all Transylvania there was sunshine, as well in the other parts of the town. During the last decades it happened only once that a thunderstorm occurred in winter in Târgu Mureș. In 12 January 2016 thunderstorm and also hail were reported from this meteorological station. A large-scale cyclone was situated over Europe. The synoptic situation (warm advection then cold front) perhaps contributed to appearance of thunderstorm. However, nowhere such phenomena were observed that day. All these unusual meteorological phenomena could be caused by the activity of Azomures. Haze and smoke clearly appear due to emission of this factory. Anthropogenic snow can develop near industrial platforms, due to emanated solid particles. In polluted air masses, aerosols may enhance cloud electrification and contribute to hail formation. An increase in the concentration of cloud condensation nuclei leads to an increase in the size of hail and ice pellets or may favour to the formation of these types of precipitation.
\end{abstract}

Keywords: Târgu Mureș, haze, industrial snow, winter hail, Azomureş

\section{INTRODUCTION}

Meteorological observations at Târgu Mureș are effectuated from the second half of 19'Th century. The weather station functions at the actual location since 29 May 2013. In the current place, environment conditions have not changed significantly, but the new site of the station is closer to Azomureș Chemical Factory, which is the biggest polluter of Mureș County. It was founded in 1962, and it is the largest Romanian fertilizer producer (mineral fertilizers with nitrogen, complex NPK fertilizers and other products) (Fig. 1). The ammonia is a specific

\footnotetext{
${ }^{1}$ National Meteorological Administration, Regional Meteorological Centre of South Transylvania, Targu Mures Weather Station, Romania, e-mail: ruszotti@yahoo.com

${ }^{2} \mathrm{PhD}$ candidate at School of Science, University of Craiova, e-mail: stancescu_mhl@yahoo.com

${ }^{3}$ NMA, RMCST, Miercurea Ciuc Weather Station, Romania, e-mail: astropityu@gmail.com
} 
pollutant of Târgu Mureș, which is continuously monitored by Regional Environmental Protection Agency Mureş. The distance between weather station and Azomureş is $2 \mathrm{~km}$ (Fig. 2).

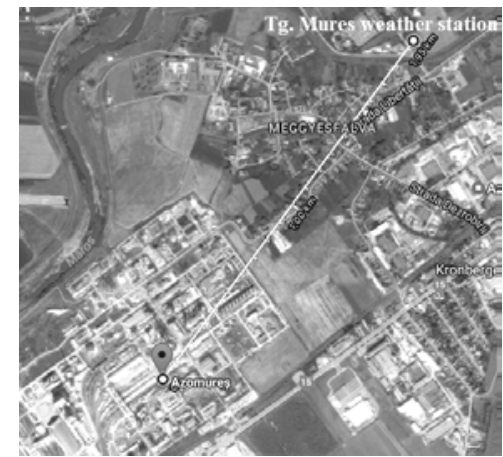

Fig. 1. The placement of Azomureş and Târgu Mureș weather station

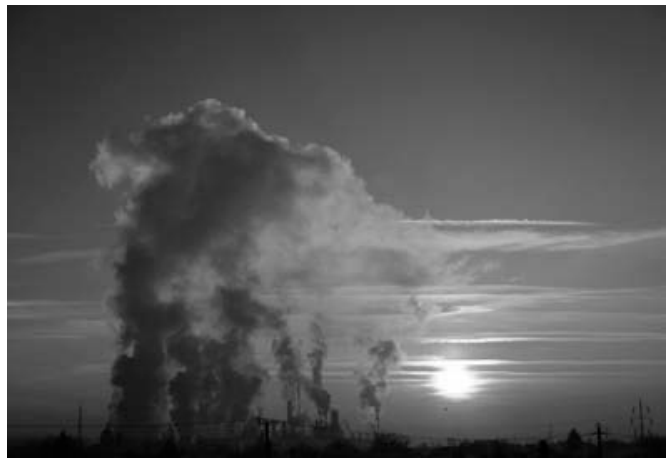

Fig. 2. Smoke from Azomureş

\section{HAZE AND SMOKE}

Haze is an aggregation in the atmosphere of very fine dry particles, invisible with the naked eye, sufficiently numerous to offer an opalescent aspect of air. The difference between this lithometeor and mist it is, that in presence of haze the relative humidity is low. The visibility may vary in large limits, able to descend below $1 \mathrm{~km}$. Smoke is an aggregation in the atmosphere of small particles, originating from different sources of combustion. There is a difference between smoke as a lithometeor and smoke clouds. The smoke has a diffuse appearance without any contour.

Haze and smoke are very rare phenomena. In the period 2003-2015 at all meteorological stations belonging to the Regional Meteorological Centre of South Transylvania (25, except Târgu Mureș) haze was registered 10 times. In contrast, at Târgu Mureș weather station in two years (2014-2015) this lithometeor or smoke was present 18 times, especially in summer. All were reported ante meridiem and persisted 1-4 hours (Fig. 3).
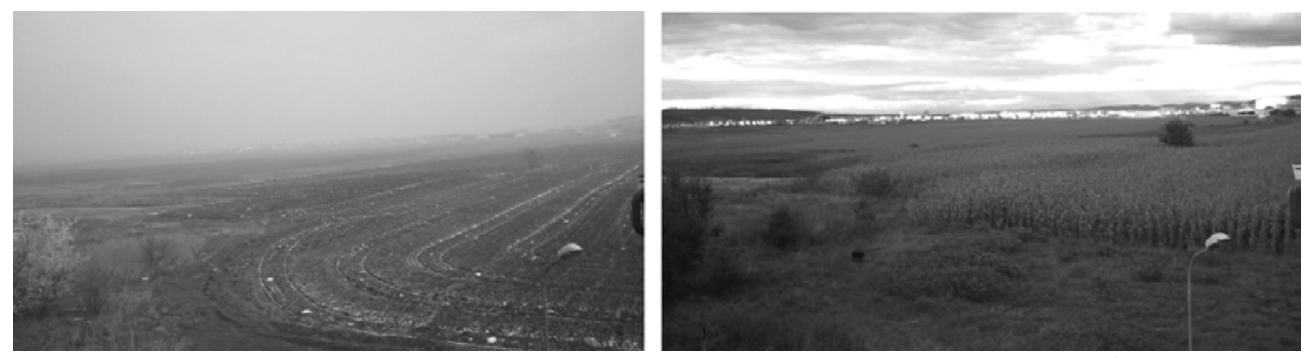

Fig. 3. Low visibility due to presence of haze at Târgu Mureș, 12 April 2015 (photo on the left). The relative humidity was below $50 \%$. 


\section{INDUSTRIAL (ANTHROPOGENIC) SNOW}

Industrial or anthropogenic snow is also a very rare meteorological phenomena. They were related for example from Switzerland (Liechti, 2004), Great Britain (Wood and Harrison, 2009), Hungary (Kolláth, 2009), USA (Simpson et al., 2015). After their works, one can conclude some features of this type of snow. Industrial snow appears under the conditions of temperature inversion. It occurs in the vicinity of heat and humidity source or due to solid particles of industrial areas. Ammonium sulfate is considered a very good hygroscopic nucleus. Stratus or Stratocumulus clouds are presents in these cases. Also fog may exist. Low temperatures favor the appearance of this phenomena. They are spread usually below 1 kilometer over industrial platforms, which causes the industrial snow.

In the Transylvanian Depression a typical phenomena is the so-called coldair pool, which appears in winter. It is a cold air mass trapped near surface in the presence of thermal inversion. The absence of vertical and horizontal movement contributes to the persistence of cold air, it sometimes may remain for a few days. As thermal inversion prevents the vertical circulations, pollutants unfold their effects at ground-level layers. In such cases the cold, foggy air mixed with industrial platform's air and aerosols, starts the cloud formation at very low level. The growth of rain drops contribute to the formation of falling precipitation (Cséki, 2010).

In 31 December 2014 an anticyclone was situated over our country having it's center north of region (Fig. 4). No precipitations were forecasted (Fig. 5).

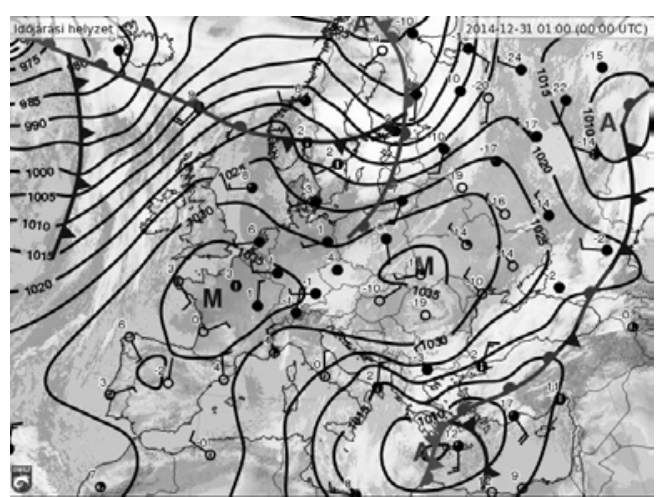

Fig. 4. Synoptic situation at 31.12.2014

(Hungarian Meteorological Service)

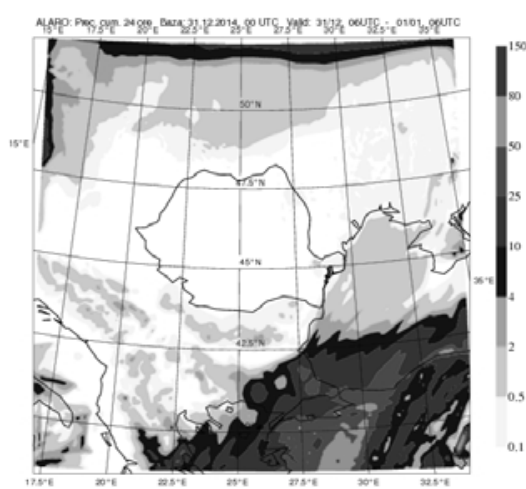

Fig. 5. Forecast of precipitation for 31.12.2016 (ALARO)

However, at Târgu Mureș a snowfall was registered between 05.00-07.40 UTC. The temperature in that period varied between $-18^{\circ} \mathrm{C}$ and $-15^{\circ} \mathrm{C}$. In addition, mist was present and the wind speed was low. Sea level pressure at meteorological station was $1040 \mathrm{hPa}$. The snowfall resulted in a $0.5 \mathrm{~mm}$ amount of precipitation and an increase of $1 \mathrm{~cm}$ of snow depth (Fig.6). Nowhere else at the meteorological 
stations belonging to the Regional Meteorological Centre of South Transylvania, no precipitations were reported (Fig. 7). Snowfall was absent even in the center or other parts of town.

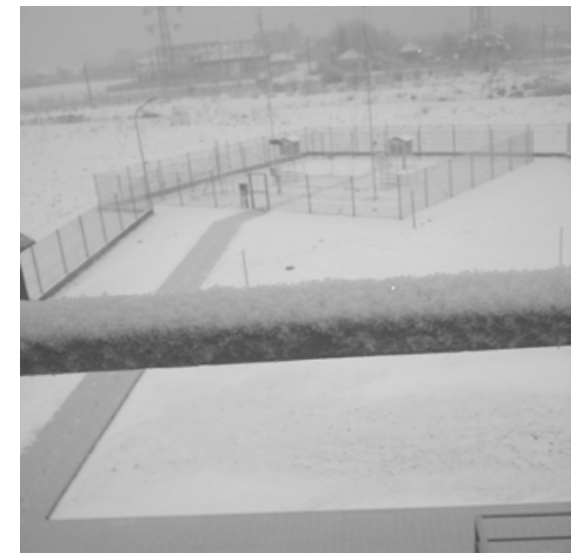

Fig. 6. The newly deposited snow in 31.12.2014

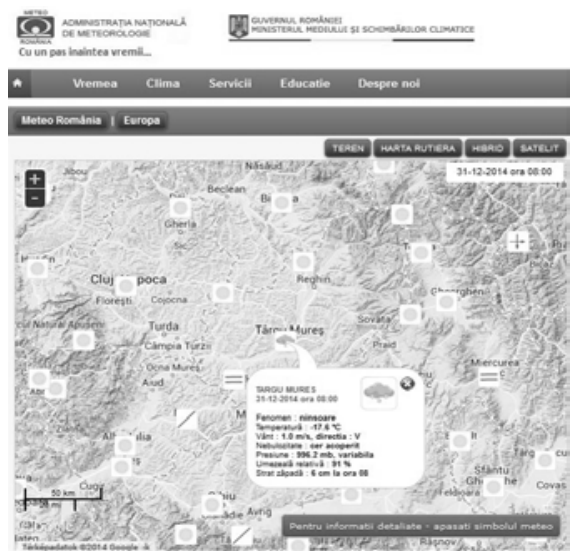

Fig. 7. It snow only at Târgu Mureș (31.12.2014), NMA

All these circumstances led us to conclude that very likely it was an industrial (anthropogenic) snowfall.

In the second part of December 2016, the above-mentioned cold-air pool was located over Transylvanian Depression. The snowfall and snow grains on 21, 22, 23 registered at Târgu Mureș meteorological station for instance didn't affect, in these three days, at all the center of the town! On 22 December 2016 snowfall was only reported from Târgu Mures. In 21 December from Braşov weather station and in 23 December from Sibiu meteorological station solid precipitations were reported (must mention that both towns are placed near mountains, so also orographic effects must take into account).

\section{THUNDERSTORM AND HAIL IN WINTER}

Thunderstorm and hail are typically warm-period meteorological phenomena. In Târgu Mureș the average of the number of days with thunderstorm is 40. Rarely do they appear in March, but usually the first day with thunderstorm is in April and May. In September, they are also present. Still can occur during October but rarely. In June and July, the number a days with thunderstorm is the highest: 10. Based on Péczely's macrosynoptic types, this phenomena occurs more ofteny in case of „Anticyclone located west of the Carpathian Basin” and „Cold front with meridional flow". Hail appears in average one time in a year, from March to September. Until last a thunderstorm was reported only once in winter: on 27'th of February 1989, but hail never (Rusz, 2016). That is why the thunderstorm accompanied by hail in 12 January 2016 was so uncommon. In winter solid precipitation may appear called "ice pellets" or "small hail". The 
difference between hail and ice pellets consists mainly in their size. The maximum diameter of hailstone in this case was $7 \mathrm{~mm}$.

In 12 January 201600 UTC the majority of Europe was under the influence of a large depression areas, with two centers originating from Iceland region. One of them was positioned in north-west parts of Germany (with the value in the center of $985 \mathrm{mb}$ ), and the other positioned at North-West of our country (with the value in center of $990 \mathrm{mb}$ ). Romania was at southwestern extremity of this depression area. At upper level, in middle troposphere (at $500 \mathrm{hPa}$ ), Romania was situated in the ascending part of a wide through, at divergence area, with temperature of $-18 \ldots-20^{\circ} \mathrm{C}$ and geopotential between $540 \mathrm{dmgp}$ and $556 \mathrm{dmgp}$. In eastern part of Europe a warm ridge was present, however with weak intensity, determined the core of cyclone to have a northeastern trajectory towards our country (Fig. 8).
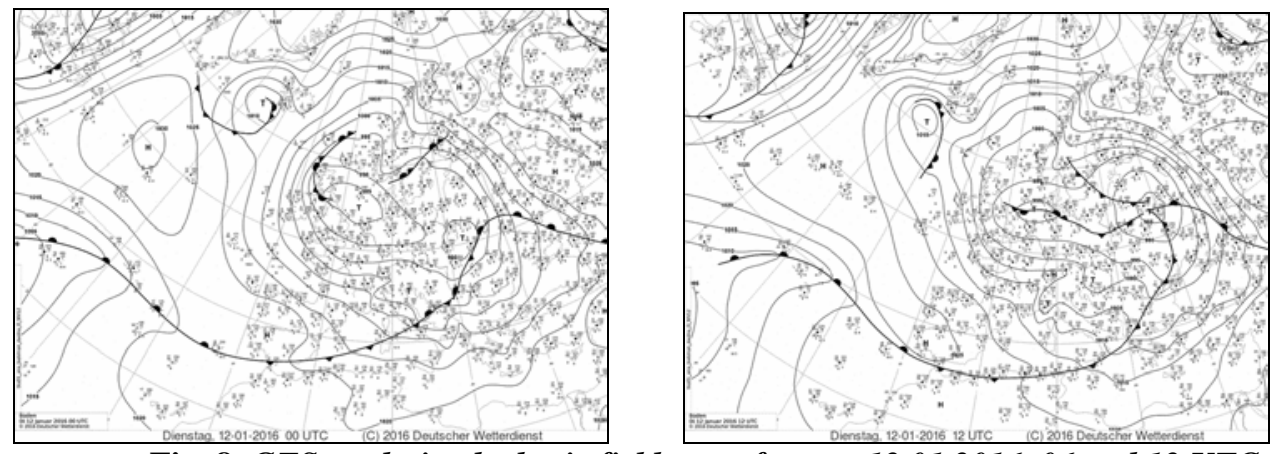

Fig. 8. GFS analysis: the baric field at surface on 12.01.2016, 06 and 12 UTC

In 12 January 2016, 00 UTC, the front was located in the high gradient areas of relative isohypses, namely in north-west of country. The map of the pressure at tropopause level shows cold advection till above north-west border of Romania, especially in the upper troposphere structures, and above south-eastern part of our country maintaining elevated tropopause heights. In case of low troposphere colder air infiltration is confirmed by isotherms present on the map of pseudo-potential equivalent temperature at $850 \mathrm{hPa}$ level in the period 12.01.2016 00 UTC-12 UTC. Therefore cold air infiltration was highlighted on the entire troposheric column, weaker in air layer between ground and $850 \mathrm{hPa}$ (having 5-6 ${ }^{\circ} \mathrm{C}$ ), but more pronounced in the middle and high levels of troposphere

The nucleus of positive advection of vorticity present at the beginning of period in the west of country crossed the northern part of our country and was embedded by upper air through. The geopotential at $500 \mathrm{hPa}$ in the interval $00-12$ UTC decreased by 12 dmgp, from 546 dmgp to 534 dmgp. The temperature at this standard level marked a decrease of $12{ }^{\circ} \mathrm{C}$ in 12 hours. In addition, in area of concern relative humidity was high: $90 \%$. On the above-mentioned date, Romania initially was in the warm section of a cyclonic core placed in north of the country. The especially southwestern air circulation favoured warm and wet air advection from Adriatic Sea basin. Up to 12 UTC cyclonic core deepened (985 mb) and has 
moved to northeast. The extremity of its afferent cold front influenced the weather of that day, in the north part of country. Between the periods 12.01.2016 00-12 UTC the surface pressure was relatively stationary, with values between 996-1000 $\mathrm{mb}$ for northern half of Romania. The temperature marked a decreases approximately $5-6^{\circ} \mathrm{C}$ at $850 \mathrm{hPa}$, and after 12 UTC the pressure increased a little bit, reaching $1003 \mathrm{mb}$ at $18 \mathrm{UTC}$ (Fig. 9).
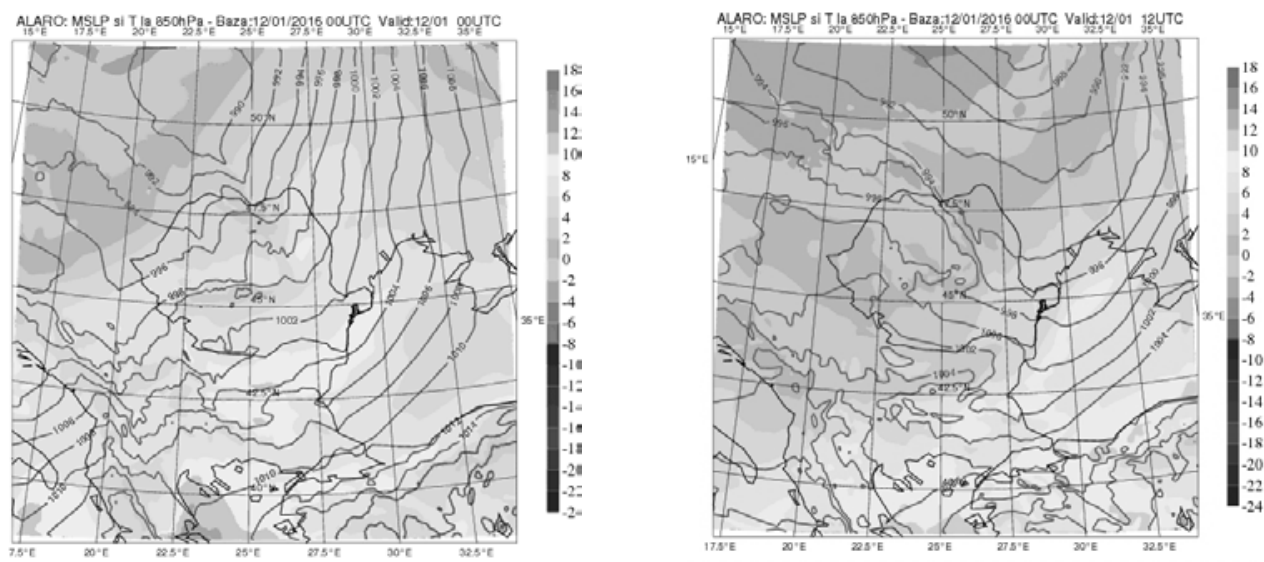

Fig. 9. ALARO analysis: the baric field at surface and the temperature at 850 hPa in 12.01.2016 00 UTC

The mean temperature for January in Târgu Mureș is $-3.5^{\circ} \mathrm{C}$, while the average of maximum temperatures is $0.4^{\circ} \mathrm{C}$ (based on climatologically database from period 1951-2015). Supported by high values of temperature (were extremely warm weather conditions in 12 January, with maximum temperatures between 5$10^{\circ} \mathrm{C}$, at Târgu Mureș the maximum temperature was $8.9^{\circ} \mathrm{C}$ ), the extremity of cold front associated with the cyclonic core from northeast of country caused unstable weather condition. This was characterized by precipitations as rain and rain showers in relatively large areas. Analyzing the surface map of isobars, one can observe that the pressure increased by $5 \mathrm{mb}$, from $995 \mathrm{mb}$ to $1000 \mathrm{mb}$ with the passage of cold front, between 06-14 UTC. At Târgu Mureș meteorological station rain showers were reported at 05.45-07.10; 07.35-07.40; 12.54-14.05; 14.10-14.15 UTC. The thunderstorm was recorded at 13.34-13.35 UTC, while hail at 13.3413.42 UTC (Fig.10). These phenomena were produced at cold sector of cyclonic core. In mountains mixed precipitation were reported. The wind intensification was present, with wind gusts of $19 \mathrm{~m} / \mathrm{s}$ at Miercurea Ciuc and Topliţa, $18 \mathrm{~m} / \mathrm{s}$ at Sibiu, Târgu Secuiesc and Sebeş, $17 \mathrm{~m} / \mathrm{s}$ at Braşov, $16 \mathrm{~m} / \mathrm{s}$ at Bâlea Lac, $15 \mathrm{~m} / \mathrm{s}$ at Târnăveni, Roşia Montană and Batoş. (Synoptic situation was described using internal material from National Meteorological Administration, Bucharest)

Implications and connections between industrial steam and pollution emissions in the formation of thunderstorms has long been observed. In surroundings prone to formation of convective events, warm steam rising from large factory stacks, cooling towers sometimes has a triggering effect causing 
towering cumulus or cumulonimbus clouds to rise near the site of the industrial facility. The event at Târgu Mureș at the 12-th of January 2016 was a weaker intensity thunderstorm which formed in the cold sector of an extratropical cyclone centered above south Poland. A cluster of shallow convective clouds were observed behind the cold front, moving in eastern direction, but none of them produced significant phenomena except the cell over Târgu Mureș.

Another interesting fact is that the cell gained it's maximal radar reflectivity of 52DBZ just above the city's area (Fig. 11). In this time lightning and hail were observed. From the radar data the height of the thundercloud could be read, a value of 6000 meters resembling a low topped thunderstorm, typical for the cold season.

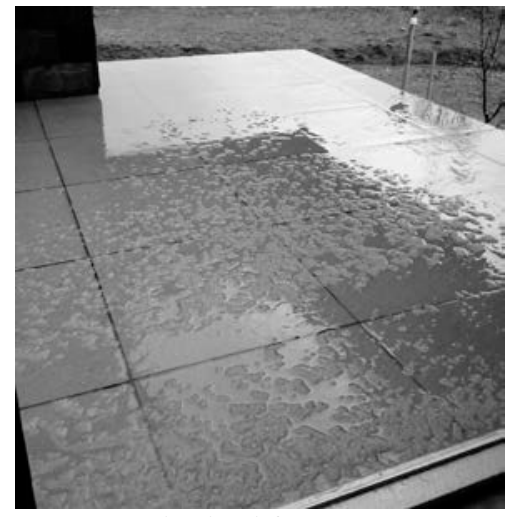

Fig. 10. The hail from 12.01.2016 quickly (foto: Pethö-Dévay I.)

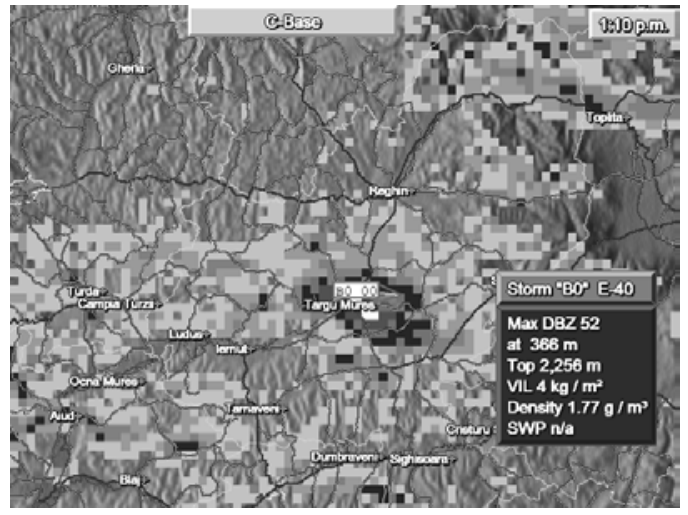

Fig. 11. Radar image showing the cell melted over Târgu Mureș area in 12.01.2016

Regarding the effects of the rising steam plume from the industrial facility, this focused excess of heat may play a role in breaking the capping inversion above the site thus providing an extra lift that may trigger a localised cell in a surrounding prone to convective developement. This cell is visually and physically attached to the exhaust site (Huff et al., 1971). Furthermore we must take into account the aerosols emanated by the factory that can act as condesation nuclei allowing more water vapour to condense thus making the cloud more dense and fueling it up by added latent heat $(\mathrm{Li}, 2011)$. Taking into consideration the relatively low CAPE surroundings and the fact that this was the only cell producing hail and thunderstorm we can't rule out the intimate connection between the presented thunderstorm and the industrial exhaust from Azomureș chemical facility.

\section{CONCLUSIONS}

Some unusual, very rare phenomena were observed at Târgu Mureș meteorological station in last years. Haze and smoke certainly were due to activity of Azomureş Chemical Factory, which is located at $2 \mathrm{~km}$ from new placement of weather station. The characteristics of industrial (anthropogenic) snow registered at 
Târgu Mureș shown the same characteristic as those reported in other countries: in the presence of anticyclone (respectively cool-air pool), the existence of snow only around Azomureş, etc. The thunderstorm and especially the hail (with maximum diameter of $7 \mathrm{~mm}$ ) from January 2016 cannot be explained exclusively by synoptic conditions (a cold sector of a cyclonic core, warm temperatures, etc.). Probably the steam and/or the aerosols from Azomureş contributed to the formation of these phenomena.

\section{REFERENCES}

1. Cséki, G. (2010), Inverziós helyzetek kialakulása a Kárpát-medencében. BSc Thesis, ELTE, Budapest.

2. Huff, F. A., Beebe, R. C., Jones, D. M. A., Morgan, G. M., Semonin, R. G. (1971), Effects Of Cooling Tower Effluents on Atmospheric Conditions in Northeastern Illinois. Circular-Illinois State Water Survey, https://www.ideals.illinois.edu/handle/2142/94436

3. Kolláth, K. (2009), Misztikus jelenségek hideg légpárnás idôjárási helyzetekben. http://www.mettars.hu/ronakor/

4. Li, Z., Niu, F., Fan, J., Liu, Y., Rosenfeld, Ding, D. (2011), Long therm impacts of aerosols on the vertical development of clouds and precipitation. Nature Geoscience, 4, 888-894.

5. Liechti, O. (2004), Industrial snow. Proceedings of the 12th SIRWEC Conference, Bingen, Germany (16-18th june)

6. Rusz, O. (2016), Zivatarok Marosvásárhelyen az 1961-2015-ös időszakban. The 8th Hungarian Geographic Conference, abstracts.

7. Simpson, B.J, Jackson., J., Lindley, T.T., Scotten, K.: Anthropogenic Snow (2015), A Case of Industrial Plant-Induced Snowfall in the Texas Panhandle. $95^{\text {th }}$ American Meteorological Society Annual Meeting

8. Wood, C.R., Harrison, R.G. (2009), Anthropogenic snowfall events in the UK: examples of urban weather modification. Weather, vol. 64, Nr 10.

9. apmms.anpm.ro, accessed on 27.12.2016

10. www.azomures.com, accessed on 28.12.2016

11. www.met.hu, accesed on 02.01.2015

12. www.meteoromania.ro, accesed on 31.12.2014 